\title{
Word Effect of Temperature, the Lighting, Workload, Noise against Eye Fatigue, General Fatigue and Stress Affect Learning Outcomes the Student Computer Users
}

\author{
I Ketut Wijaya \\ Office Address: Faculty of Electrical Engineering (Ergonomic Work Physiology) University of Udayana, \\ Badung-Bali. \\ Home address: Jalan. Gn Batukaru 42 A Denpasar. \\ University of Udayana, Bukit Jimbaran, Badung-Bali
}

\begin{abstract}
Working with a computer is done in the time period long enough. Computers are the best medium currently in appearance and way of working, because computers can assist in completing the work more quickly, efficiently and very easy to use. With the convenience offered by computers, almost all of the work can be done with a computer. The computer is a needs in supporting the work and a good communication tool.

Computers is useful in life, but can also cause problems for users, can affect the computer user's health. Using of the computer can cause eye fatigue, general fatigue and stress, due to not understanding in determining the temperature, light, the eye distance to the computer and work load in the room. To be able to know due to computer use like the eye fatigue, general fatigue, stress and to the increase learning outcomes, research is done with a sample 15 of people with the same subject design. In this study sought differences a variable before and after the repair is done by performing a recalculation on temperature and light intensity for get standardized conditions. Standard conditions obtained are expected to reduce complaints: eye fatigue, a common complaint, workload and stress to improve learning outcomes. The difference in the data before and after the repair, the analysis is done using independent-sample t-test (t-test group), at the 5\% significance level.

After a redesigned on the environmental temperature is obtained decreases the standard cold temperatures people Indonesia work, of were condition originally 28.00 degrees C be 25.83 degrees Celcius, illumination of 110 lux to 246.67 lux. Distance from the eye to the computer 48.267 be 66.300 $\mathrm{cm}$. Eye fatigue decrease by $60 \%$, general fatigue decreased by $44.1 \%$ and job stress decreased $60 \%$ so that occur increase in the learning outcomes by $18 \%$. It can be concluded that due to the improvements made to the environmental standards can reduce Eyestrain and stress in work.
\end{abstract}

Keywords : Computers, Complaint, Learning Outcomes the Student

\section{INTRODUCTION}

The computer is a tool used to facilitate in solving problems on the job. A wide range of computer equipment being traded in the market and the market share of this tool is to reach young children and the elderly. Computers can be used to communicate over long distances each other at a distance almost unlimited with low cost. The computer was created in the form of a very attractive in different colors shapes and sizes. Computer capabilities continue to evolve, for to meet the desire the criteria of market share. With the growing capabilities of computers and accessories that are owned, making the computer more interesting.

Computers used as a means of practicum in a computer lab at the department of Electrical Engineering. The use of computers which no notice of the conditions of temperature, lighting, noise, and the workload can cause eye fatigue and stress. As a result of the fatigue and stress can affect the learning outcomes. Besides the temperature, lighting, noise, and workload, distance see the eyes a computer must be fully maintained to avoid faster eye fatigue. The results of a preliminary study conducted get the eye fatigue score by $81 \%$ and stress work-related $86 \%$. The results of a preliminary study looked eyestrain and work stress were high enough, cause to be done an improvement through a study to determine the effect of temperature, lighting, noise, and workload against eyestrain and stress.

From the description above be must there are improvements on temperature, lighting, noise and workload in the lab which is used practicum student of Information Engineering University of Udayana to derive eyestrain, general fatigue and stress. Redesign conducted in a computer lab is an improvement on the temperature and lighting with to perform recalculations and improvements made on the a noise if the noise be at a disturbing rate.

\section{MATERIALS AND METHODS}

The material in this research is the student which practicum on computer lab at the University of Udayana EIektro Technique with a sample 15 people, who ordinary to use the computer. Tool data retrieval used in this study is a questionnaire to measure the level of eyestrain, workload and stress. Retrieval of data on temperature and illumination with a thermometer and a wet-dry, lux meter. Noise is measured with a sound level meter.

Differences environmental data, eyestrain and stress tested by using independent sample t-test, at a significance level of 5\%.

\section{RESULTS AND DISCUSSION \\ 3.1 Environmental Conditions}

Environmental conditions are conditions of temperature, lighting and noise at the time of the study. Environmental conditions are conditions of temperature, lighting and noise at the time of the study. Environmental conditions in the laboratory where the research done redesign or repairs to get the appropriate environmental conditions. For temperature and lighting performed recalculation in accordance with the needs of temperature and light intensity. And the noise did 
not done repairs because of the noise before and after the repair did not affect the results of research $\mathrm{p}>0.05$.

Table 1. Analysis test the difference of environmental conditions in the laboratory of computer department of electrical engineering

\begin{tabular}{|c|c|c|c|c|c|}
\hline \multirow{3}{*}{ Variables } & Before Redesign & After Redesign & \multirow{3}{*}{$\begin{array}{l}\text { The Mean } \\
\text { Difference }\end{array}$} & \multirow{3}{*}{$\begin{array}{c}\text { Value } \\
\mathrm{t}\end{array}$} & \multirow{3}{*}{$\begin{array}{c}\text { Value } \\
\mathrm{P}\end{array}$} \\
\hline & & & & & \\
\hline & Mean & Mean & & & \\
\hline
\end{tabular}

\begin{tabular}{|c|c|c|c|c|c|c|c|}
\hline \multicolumn{8}{|l|}{ Temperature } \\
\hline of Dry $\left({ }^{0} \mathrm{C}\right)$ & 28,00 & 0,50 & 25,83 & 0,76 & 2,17 & 4,91 & $0,04 *$ \\
\hline \multicolumn{8}{|l|}{ Temperature } \\
\hline of Wet $\left({ }^{0} \mathrm{C}\right)$ & 23,67 & 1,04 & 20,83 & 0,58 & 2,84 & 4,71 & $0,04 *$ \\
\hline $\begin{array}{l}\text { Humidity } \\
(\%)\end{array}$ & 72,67 & 4,04 & 62,17 & 0,58 & 10,50 & 5,25 & $0,03 *$ \\
\hline $\begin{array}{l}\text { Noise }(\mathrm{dB}) \\
\text { (A) }\end{array}$ & 33,87 & 8,07 & 33,77 & 7,63 & 0,10 & 0,30 & 0,78 \\
\hline $\begin{array}{l}\text { The Light } \\
\text { Intensity } \\
\text { (lux) TL } \\
2 \times 36 \text { watt }\end{array}$ & 110,00 & 11,83 & 246,67 & 8,16 & -136.67 & $\begin{array}{c}- \\
23,29\end{array}$ & $0,001 *$ \\
\hline
\end{tabular}

Paired Samples T Test, $(\mathrm{p}<0.05$.

\subsubsection{The Temperature of the Environment}

The results of measurements temperatures in the lab with an area of $55.09 \mathrm{~m}$ and height $3.44 \mathrm{~m}$ obtained dry temperature before redesigned the average temperature of $28.00 \mathrm{C}$ and dry temperature data obtained after the redesign is $25.83 \mathrm{C}$. Different test results showed a large value of $p=0.04$. That means the dry temperature between before and after the redesign significantly different with $\mathrm{p}$ value $<0.05$ experiencing decreased by $7.75 \%$. With the obtained temperature 25.83 degrees Celsius in accordance with National Standards of Indonesia. This condition can affect the body at the time of studing in the laboratory. This finding is appropriate with a report by the Indonesian National Standard 03-6572-2001 about on design of ventilation systems and air conditioning in buildings in Indonesia, to design the room generally $25 \pm 1$ degree Celsius. With a temperature of 25.83 degrees Celsius is in accordance with the national standards of Indonesia. At standard temperature is already felt cold to work in the room on the conditions a Indonesia people. Wet temperature average a before redesigned was $23.67 \mathrm{C}$ and wet temperature average after redesigned was $20.67 \mathrm{C}$. The analysis showed that the value of $p=0.04$. That means the wet temperature before and after redesigned differed significant $\mathrm{p}<0.05$, a drop in wet temperature between before and after was redesigned adalah $12.67 \%$. This condition can affect fatigue at the time of studing in the laboratory.

Average humidity before redesigned is $72.67 \%$ and Average humidity after redesigned is $62.17 \%$. This finding in accordance with the the findings of the research Centre of Meteorology and Geophysics Agency Region III for the period June 2008 Denpasar, which is between 62 to $92 \%$ (Bali Province , 2008). Humidity in the computer lab should be given attention, because in the laboratory conducted practicum in a confined space, so there is no air circulation. This is done so that moist air does not affect the student body who do practice in the laboratory and humid air can cause the body to become weak because conditions are too moist.

\subsubsection{Intensity Light}

In the computer lab Department Elekto almost entirely using electricity for lighting. The position and layout of the room is not suitable for use sunlight which causing glare. Conditions lighting before redesigned uses two lamps TL2x36 watt. The intensity of light produced an average of 110.00 lux and after the recalculated uses eight lamps obtain light intensity was 246.67 lux. Increased light intensity as big as 136.67 lux for get standards. Increased the intensity of light is is intended so that the eyes do not tire quickly and can improve learning outcomes.

\subsubsection{Noise}

Noise is also a risk factor in the work, so the noise must be in standard conditions specified in the noise classification on the office (Manuaba, 1998). Noise must be controlled properly to be able to produce the expected working conditions. The results of the average noise before redesigned the computer lab amounted to $33.87 \mathrm{~dB}$ (A) and noise average after redesigned is $33.77 \mathrm{~dB}(\mathrm{~A})$. Thus the noise level after the redesigned was also very quiet on the classification that is between 30-40 dB (A) (Manuaba, 1998). Ibach77 (2008) stated that the noise limits that make the work environment is comfortable at $60 \mathrm{~dB}(\mathrm{~A})$. So the noise in this study, between before and after the redesign includes a category calm. Noise that occurs in this study do not affect the results of research because $p>0.05$ or before and after the redesigned is the same noise level. Conditions of Noise in the computer lab which closed and away from highway traffic does not affect the results of lab work. For it condition level noise before and after practicum is the same that is at the level of classification calm.

\subsection{Distance Eyes Against the Computer}

Table 2. Analysis of Distance a eye With Computers Before and the After Repair ( $N=15)$

\begin{tabular}{|c|c|c|c|c|c|c|c|}
\hline \multirow{2}{*}{ Variables } & \multicolumn{2}{|c|}{ Before Redesign } & \multicolumn{2}{|c|}{ After Redesign } & \multirow{2}{*}{ Difference } & \multirow{2}{*}{$\begin{array}{l}\text { Value } \\
\text { of } t\end{array}$} & \multirow{2}{*}{$\begin{array}{l}\text { Value } \\
\text { of } p\end{array}$} \\
\hline & Mean & SD & Mean & SD & & & \\
\hline \multicolumn{8}{|l|}{$\begin{array}{l}\text { Distance } \\
\text { eyes to }\end{array}$} \\
\hline Computer & 48.267 & 4.964 & 66.300 & 1.192 & 18.033 & 16.620 & 0.000 \\
\hline
\end{tabular}

Paired Samples T Test, $(\mathrm{p}<0.05$.

Average distance of the student eye against computer before done the repair is $48.267 \pm 4.964$ and after done repair is $66.300 \pm 1.192$. The results of analysis which were obtained from repair the distance the eye to the computers is the differently and meaningful with $\mathrm{p}<0.05$. The results of this analysis can affect in reducing eye fatigue. There are some opinions say that: most operators computer choose a distance between 45-75 cm (FEOSH. 2008). Recommendations distance view to the computer from 45.7 to $71.1 \mathrm{~cm}$ has been recognized by the ergonomics standard (Sweere. 2007; Wilkinson, 2006). According to TWCC (2007) more people choose the sight distance to the computer between 50.8 to 66 $\mathrm{cm}$.

\subsection{Workload}

The workload is load received by students while performing a job due to practicum itself. Workloads can also be accepted by the students due to the additional workload as a result of the environment (temperature, lighting and noise) are not 
appropriate. Workload before and after the improvements can be seen in Table 3 .

Table 3. Analysis Workload Before and After Repair ( $\mathbf{N}=$ 15)

\begin{tabular}{|c|c|c|c|c|c|c|c|}
\hline \multirow{2}{*}{ Variables } & \multicolumn{2}{|c|}{$\begin{array}{c}\text { Before } \\
\text { Redesign }\end{array}$} & \multicolumn{2}{|c|}{ After Redesign } & \multirow{2}{*}{ Difference } & \multirow{2}{*}{$\begin{array}{c}\text { Value } \\
\text { of } t\end{array}$} & \multirow{2}{*}{$\begin{array}{c}\text { Value } \\
\text { of } p\end{array}$} \\
\hline & Mean & SD & Mean & SD & & & \\
\hline \multicolumn{8}{|l|}{ Workload } \\
\hline \multicolumn{8}{|l|}{ Before } \\
\hline Practicum & 31.333 & 1.234 & 31.267 & 1.1 & 0.067 & 1 & 0.334 \\
\hline \multicolumn{8}{|l|}{ Workload } \\
\hline \multicolumn{8}{|l|}{ After } \\
\hline Practicum & 67.667 & 2.717 & 37.800 & 4.057 & 29.867 & 27.498 & $0,000 *$ \\
\hline & & & & & & - & \\
\hline Difference & 36.333 & 2.992 & 6.533 & 3.925 & 29.8 & 27.290 & $0,000 *$ \\
\hline
\end{tabular}

Paired Samples T Test, $(\mathrm{p}<0.05$.

Workload after practicum before and after the repair decreased with a mean of $29.867(44.1 \%)$. This suggests that the improvements made through improvements to temperature and lighting are very successful in reducing the workload.

\subsection{Fatigue Eye}

Eye fatigue can be caused by poor lighting, thus adversely affecting the student to see at the computer in the computer lab Udayana University Department of Electrical Engineering. In addition, the distance of the monitor to the subject's eyes are too close can accelerate eye fatigue. Tirtayasa, et al (1989) states that employees who work in close proximity to the object in the long term and conditions that are less compliant lighting can cause eye fatigue.

Table 4 Analysis of Eyestrain Before and After Repair $(\mathbf{N}=15)$

\begin{tabular}{|c|c|c|c|c|c|}
\hline \multirow{2}{*}{ Variables } & Before Redesign & After Redesign & \multirow{2}{*}{$\begin{array}{l}\text { The mean } \\
\text { difference }\end{array}$} & \multirow{2}{*}{$\begin{array}{c}\text { value } \\
\text { of } t\end{array}$} & \multirow{2}{*}{$\begin{array}{l}\text { value } \\
\text { of } p\end{array}$} \\
\hline & Mean & Mean & & & \\
\hline
\end{tabular}

\begin{tabular}{|c|c|c|c|c|c|c|c|}
\hline \multicolumn{8}{|l|}{ Eyestrain } \\
\hline \multicolumn{8}{|l|}{ Before } \\
\hline Practicum & 9.200 & 1.014 & 8.933 & 1.223 & 0.267 & 1.468 & 0.164 \\
\hline \multicolumn{8}{|l|}{ Eyestrain } \\
\hline \multicolumn{8}{|l|}{ After } \\
\hline Practicum & 31.600 & 2.028 & 12.733 & 2.017 & 18.867 & 39.573 & 0.000 * \\
\hline Difference & 22.400 & 2.063 & 3.800 & 1.521 & 18.600 & 42.833 & $0.000 *$ \\
\hline
\end{tabular}

Paired Samples T Test, $(\mathrm{p}<0.05$.

The results score eyestrain after practicum before the redesigned was $31.600 \pm 2.028$. Seeing the results of eye fatigue scores were obtained prior to the redesign, this condition can interfere so need done redesigning. Score eyestrain after practicum after the redesign was 12,733 . This eyestrain is different meaningful with $\mathrm{p}<0.05$. Decreased eyestrain by $60 \%$. Reduction of eye fatigue is caused by the addition of the light intensity as big 136.67 lux.

According Sumardiyono (2004) there was a highly significant correlation between the intensity of the lights with eyestrain on labor at cucuk section in PT. Iskandartex Surakarta. Siswatiningsih (1998) states that there is a significant relationship between the intensity of illumination with eyestrain labors sewing machine operator at PT. Rodeo Semarang. Aryanti (2006) states that there is a significant relationship between lighting and temperature with eyestrain with $p<0.05(p=0.024)$. Findings Sumardiyono (2004) and Siswatiningsih (1998) have in common on this study namely use light intensity 250 lux. Legaloperate (2009) found that approximately $77 \%$ the monitor users which is not ergonomic will have complaints on the eye. According to Dewi, et al (2009) states that there is a correlation between the old using a computer with eye fatigue for 8 hours.

The conclusion that can be drawn from the above findings is the addition of light intensity can lower power eye accommodation so that eyestrain be experienced decreasing.

\subsection{General Fatigue On Time Doing Practicum}

Fatigue is a result of working a result as from environment (temperature and light) that does not comply with the conditions of employment. Working conditions such as temperature and light affect the student body and can accelerate fatigue. Fatigue before and after the improvements made can be seen in Table 5 .

Table 5. Fatigue analysis Before and After is Performed Repair $(\mathbf{N}=15)$

\begin{tabular}{|c|c|c|c|c|c|c|c|}
\hline \multirow{3}{*}{ Variables } & \multicolumn{6}{|c|}{ After } & \multirow{3}{*}{$\begin{array}{c}\text { Value } \\
\text { of } p\end{array}$} \\
\hline & \multicolumn{2}{|c|}{ Before Redesign } & \multicolumn{2}{|c|}{ Redesign } & \multirow{2}{*}{$\begin{array}{c}\text { Mean } \\
\text { Difference }\end{array}$} & \multirow{2}{*}{$\begin{array}{l}\text { Value } \\
\text { of } t\end{array}$} & \\
\hline & Mean & SD & Mean & SB & & & \\
\hline \multicolumn{8}{|l|}{ General } \\
\hline \multicolumn{8}{|l|}{ Fatigue } \\
\hline \multicolumn{8}{|l|}{ Before } \\
\hline Practicum & 31.333 & 1.234 & 31.267 & 1.100 & 0.067 & 1.000 & 0.334 \\
\hline \multicolumn{8}{|l|}{ General } \\
\hline \multicolumn{8}{|l|}{ Fatigue } \\
\hline \multicolumn{8}{|l|}{ After } \\
\hline Practicum & 67.667 & 2.717 & 37.800 & 4.057 & 29.867 & 27.498 & $0,000 *$ \\
\hline \multicolumn{8}{|l|}{ Difference } \\
\hline & & & & & & - & \\
\hline & 36.333 & 2.992 & 6.533 & 3.925 & 29.800 & 27.290 & $0,000 *$ \\
\hline
\end{tabular}

The mean score of general fatigue after practicum and before the redesigned was $67,667 \pm 2717$, the mean score of general fatigue after practicum and after the redesigned was $37,800 \pm$ 4057. The mean score decreased general fatigue after done the repair is equal to 29867 (44\%). Thus it is certain that after the temperature and lighting improvements occur the decline in the general fatigue.

\subsection{Of Occupational Stress}

Results from an average score of job stress prior redesigned from $29.98 \pm 0.39$ (total value $>24=$ high stress). Having redesigned the stress level to $16.28 \pm 1.10$ (total score of 1024 = stress level becomes). Job stress before and after redesigned significantly different with value $\mathrm{p}<0.05$ and occur decreased by 18.867 (60\%).

Table 6. Analysis Stress Before and After Repair $(\mathrm{N}=15)$ 


\begin{tabular}{|c|c|c|c|c|c|c|c|}
\hline \multirow{2}{*}{ Variables } & \multicolumn{2}{|c|}{ Before Redesign } & \multicolumn{2}{|c|}{ After Redesign } & \multirow{2}{*}{$\begin{array}{l}\text { The mean } \\
\text { difference }\end{array}$} & \multirow{2}{*}{$\begin{array}{c}\text { value } \\
\text { of } t\end{array}$} & \multirow{2}{*}{$\begin{array}{l}\text { value } \\
\text { of } p\end{array}$} \\
\hline & Mean & SD & Mean & SD & & & \\
\hline \multicolumn{8}{|l|}{ Of } \\
\hline \multicolumn{8}{|c|}{ Occupational } \\
\hline Practicum & 9.200 & 1.014 & 8.933 & 1.223 & 0.267 & 1.468 & 0.164 \\
\hline \multicolumn{8}{|l|}{ of } \\
\hline \multicolumn{8}{|l|}{ Occupational } \\
\hline Stress After & & & & & & & \\
\hline Practicum & 31.600 & 2.028 & 12.733 & 2.017 & 18.867 & 39.573 & 0.000 \\
\hline Difference & 22.400 & 2.063 & 3.800 & 1.521 & 18.600 & 42.833 & 0.000 \\
\hline
\end{tabular}

Paired Samples T Test, $(p<0.05$

Stress can affect the student body because the student a work in its not natural state. Stress caused by the environment such as the lack of regulation on the temperature that causes fatigue and stressful. Lack of light intensity that causing working with unnatural way caused stress and practicum in the computer lab conducted on condition monotonic, this affects the onset of job stress.

Conditions laboratory are not standard potentially be a cause of stress, difficulty concentrating and decreased work productivity. If the laboratory is not comfortable, heat, air circulation is inadequate, the room was too crowded by people and working tools, working environment less clean, noisy, impacted big on the comfort of work that causes stress.

\subsection{Learning Outcome}

Improvements to temperature and lighting will affect the workload, eye fatigue, general fatigue and stress. Learning outcomes measured by the length of time working on and test score of student learning. Improvement scores on workload, eye fatigue, general fatigue and stress of work will affect increase in the learning outcomes.

Table 7. Analysis is Learning Outcomes Before and After Repair ( $\mathbf{N}=15)$

\begin{tabular}{|c|c|c|c|c|c|}
\hline \multirow{2}{*}{ Variables } & Before Redesign & After Redesign & \multirow{2}{*}{$\begin{array}{c}\text { Mean } \\
\text { Difference }\end{array}$} & \multirow{2}{*}{$\begin{array}{c}\text { Value } \\
\text { of } t\end{array}$} & \multirow{2}{*}{$\begin{array}{c}\text { Value } \\
\text { of } p\end{array}$} \\
\hline & Mean & Mean & & & \\
\hline
\end{tabular}

\begin{tabular}{llllllll}
\hline $\begin{array}{l}\text { Old do } \\
\text { the exam } \\
\text { (minutes) }\end{array}$ & 104.000 & 5.682 & 84.600 & 2.473 & 19.400 & 10.980 & $0.000^{*}$ \\
$\begin{array}{l}\text { Value } \\
\text { Test }\end{array}$ & 70.800 & 3.629 & 82.867 & 3.925 & 12.067 & -9.949 & $0.000^{*}$ \\
\hline
\end{tabular}

Paired Samples T Test, $(\mathrm{p}<0.05$

Increased the average of learning outcomes is seen from time a needed to do the exam is decreased 19.400 minutes and test scores increased with scores value of 12.067. Improved learning outcomes due to improvements made is $18 \%$. Thus, improvements temperature and lighting can affect the learning outcomes.

\section{CONCLUSION}

Based on the description of the above discussion can be made the following conclusions,
1. Improvements in temperature, light intensity and adjust the distance of the eye with a computer is done to reduce eye fatigue, general fatigue and workload. Decrease eye fatigue, general fatigue and workload can reduce job stress.

2. Work stress affects student in computer lab at a worrying rate, that can affect learning outcomes. To reduce work stress, needed is repairs on temperature, light intensity by do re-calculation so as to improve learning outcomes.

\section{ACKNOWLEDGMENTS}

Thanks to Professor Adi Putra and Professor Dewa Sutjana who have provided input for this paper. Hopefully this paper a lot of benefits.

\section{REFERENCES}

[1] Ankrum, D. R. 2008. New Visual Consideration at Computer Workstasions. Available from URL:http://www.google.com/ergonomics booklet.html.

[2] Aryanti (2006). The relationship between the intensity of Illumination and Air Temperature with eye fatique on Administration Section in the PT. Hutama Region IV Work Semarang. Sekripsi. State University of Semarang.

[3] National Standardization Agency of Indonesia (2004). Values Threshold heat Climate Work (heat), Noise, Hand-Arm Vibration, Radiation and Radiation rays Ultra Purple in the Workplace.

[4] Bali Province (2008). Center for Meteorology and Geophysics Agency Region III for the period June 2008 Denpasar, which is between 62 up to $92 \%$.

[5] Bakta, I M. (1997). Papers Design Research. Inservice a day: About Research Methods. Denpasar: Medical Faculty Udayana University.

[6] Chang, P.T. dan Konz (1993). Director Size VS Viewing Distance On VDT, Dalam H. Luzak, A. Cakir (EDS), proseding of the Third International scientific Conference On Work With Display Unit, 1, 268-272. Nort Holland; Elsevior Science Publisher B.V.

[7] Colton, T. (1985). Statistics in Medicine. Boston: Little Brown and Company. 142 - 145.

[8] Darmasetiawan, C. and Puspakesuma, L. (1991). Techniques Lighting, and Lighting layout. Thesis. Universita Indonesia.

[9] Dewi. Rico and Hamzah (2009). Factors Related With Fatigue Eye On Computer Operator in Office Samsat Palembang in 2009. Theses. University of Palembang Srivijaya.

[10] FEOSH (2008). Creating a Healthy Workstation Environment. Available at URL:http://www.eh.doe.gov/feosh/pubs/ergo-12-10.pdf. Diakses 25 Pebruari 2009.

[11] Grandjean, E. 1988. Fitting the Task to The man. A Textbook of Occupational Ergonomics. London: Taylor \& Francis Ltd. 6 - 15; 22 - 47; 52 - 76; 82 - 98; $143-$ $145 ; 155$.

[12] Hadi, S. 1995. Reasearch Methodology Volume IV. Yogyakarta. Publishers Andi Offset.

[13] Harten and Setiawan 1985. Installation of Electrical Power Lines. Volume 2. Binacipta Bandung. 
[14] Ibach77 2008. Temperature Room and Limits Noise Work Environment To Increase Productivity. Outcomes Research. Accessed Date 3 September 2009.

[15] Isaac, S., Michael, W.B. 1971. Handbook in Research and Evaluation, A Colection of Principles, Methods and Strategies Useful in Education and The Behavioral Sciences. California : Robert R. Knaap Publisher.

[16] Karyono 2001. Temperature on Tall Buildings In Jakarta. Tesis.Universitas of Jakarta.

[17] Legaloperate 2009. The Hazard of Computers to health. Theses. State University of Malang.

[18] Rini 2001. Team e-psikologi.com. UI Jakarta, March 1, 2002.

[19] Siswatiningsih 1998. Relationship Between Intensity Illumination With eyestrainlabor on the sewing part in PT. Rodeo Semarang. Theses. Diponegoro University.
[20] Subagyo 2009. Effect of Noise Against Productivity Levels. Theses. State University of Yogyakarta.

[21] Sumardiyono 2004. Relationships Intensity Illumination With Eyestrain On The Labor section Cucuk in PT. Iskandartex Sukarta. Thesis. UNS.

[22] Tirtayasa, I K., I D.P. Sutjana. I N. Anteng Aryana. D.M. Kusmayuni dan Suyasning H.I. 1989. Eye Strain of Garmen Workers in Denpasar Bali. J.Human Ergol. 18 (1): $100-101$.

[23] TWCC. 2007. Workstation Adjustments. Available at URL:http://www.twcc.state.tx.us/information videoresources / wrkstn.pdf. Diskses 23 Juni 2008 